\title{
Analisis Ketepatan Kode Diagnosis Utama Kasus Persalinan Sebelum dan Sesudah Verifikasi pada Pasien BPJS di Rsup Dr. Soeradji Tirtonegoro Klaten
}

\author{
Nandani Kusuma Ningtyas ${ }^{1}$, Sri Sugiarsi ${ }^{2}$, Astri Sri Wariyanti ${ }^{3}$ \\ Prodi D4 Manajemen Informasi Kesehatan STIKes Mitra Husada Karanganyar1,2,3 \\ nandanikn@gmail.com ${ }^{1}$, sri.sugiarsi14@gmail.com ${ }^{2}$, astri_mhk20@yahoo.com ${ }^{3}$
}

Submitted 14 September 2018 Revised 1 Oktober 2018 Accepted 21 Januari 2019

\section{ABSTRAK}

Latar Belakang: Berdasarkan hasil survei pendahuluan di RSUP dr. Soeradji Tirtonegoro Klaten ditemukan perbedaan kode diagnosis utama pada 5 dari 10 dokumen rekam medis pasien BPJS kasus persalinan sebelum dan sesudah verifikasi Tujuan: Mengetahui ketepatan kode diagnosis utama kasus persalinan sebelum dan sesudah verifikasi pada pasien BPJS di RSUP dr. Soeradji Tirtonegoro Klaten.

Metode: Jenis penelitian analitik komparatif dengan pendekatan cross sectional. Populasi yaitu dokumen rekam medis pasien rawat inap JKN BPJS kasus persalinan Triwulan I tahun 2017. Besar sampel 50 dokumen dengan teknik pengambilan sampel sistematis random sampling. Instrumen berupa checklist, dan daftar pertanyaan. Cara pengumpulan data menggunakan observasi dan wawancara tidak terstruktur. Teknik pengolahan data collecting, editing, coding, entering, processing, cleaning dan penyajian data. Analisis data menggunakan uji Fisher exact test

Hasil: Ketepatan kode diagnosis utama kasus persalinan sebelum verifikasi 25 (50\%) tepat dan 25 (50\%) tidak tepat. Ketepatan kode diagnosis utama kasus persalinan sesudah verifikasi 29 (58\%) tepat dan $21(42 \%)$ tidak tepat. Hasil uji statistik diperoleh p value $>0,05(0,274>0,05)$.

Kesimpulan: Tidak ada perbedaan ketepatan kode diagnosis utama kasus persalinan sebelum dan sesudah verifikasi pada pasien BPJS. Disarankan dalam penentuan kode diagnosis utama didasarkan aturan koding ICD-10 dan verifikator internal tetap melakukan pengecekan terkait kode diagnosis.

Kata Kunci: kode diagnosis utama; verifikasi; BPJS; INA-CBG

\section{ABSTRACT}

Background: Based on the preliminary survey at RSUP dr. Soeradji Tirtonegoro Klaten found the main diagnosis code differences in 5 out of 10 BPJS patient medical record for labor cases before and after verification.

Objective: To determine the accuracy of the main diagnosis codes of labor cases before and after verification in BPJS patients at $d r$. Soeradji Tirtonegoro KlatenGeneral Hospital.

Methods: Type of research is comparative analytic with cross sectional approach. The population is medical record of JKN BPJS inpatients in the first quarter of 2017. The samples are 50 documents use systematic sampling technique. The instrument is checklist and list of questions. Collecting data use observation and unstructured interviews. Data processing use collecting, editing, coding, entering, processing, cleaning and presenting data. Data analysis used Fisher exact test.

Results: The accuracy of the main diagnosis codes of labor cases before verification is $25(50 \%)$ correct and $25(50 \%)$ incorrect. The accuracy of the main diagnosis code for labor cases after verification is $29(58 \%)$ correct and 21 $(42 \%)$ incorrect. The results of Fisher exact test were obtained p value (0.274)>0.05.

Conclusion: There is no difference in the accuracy of the main diagnosis codes of labor cases before and after verification in BPJS patients. It is recommended in determining the main diagnosis code based on the coding rules in ICD-10 and the internal verifier still check the diagnosis code.

Keywords: main diagnosis code; verification; BPJS; INA-CBG 


\section{PENDAHULUAN}

Menurut (Permenkes RI, 2016) Peraturan No 76 tahun 2016, metode pembayaran dalam implementasi Jaminan Kesehatan Nasional (JKN)yang diterapkan pada Fasilitas Kesehatan Rujukan Tingkat Lanjut (FKRTL) disebut case based payment (casemix) atau pengelompokan diagnosis dan prosedur dengan mengacu pada ciri klinis yang mirip/sama dan penggunaan sumber daya/biaya perawatan yang mirip/sama menggunakan software grouper Indonesia Case Based Group (INA-CBG).

P e n g e lo m p ok a n I N A - C B G menggunakan sistem kodefikasi dari diagnosis akhir dengan aturan ICD-10 Revisi Tahun 2010. Ketepatan koding diagnosis dan tindakan/prosedur sangat berpengaruh terhadap hasil grouper dalam aplikasi INACBG. Berdasarkan (WHO, 2010) diagnosis utama adalah kondisi utama yang ditangani atau diselidiki selama episode perawatan kesehatan yang relevan. Jika ada lebih dari satu kondisi seperti itu, yang paling bertanggung jawab untuk penggunaan sumber daya terbesar harus dipilih sebagai diagnosis utama.

Apabila dalam pengodean diagnosis atau tindakan/prosedur koder menemukan kesulitan maupun ketidaksesuaian dengan aturan umum pengodean, maka koder harus melakukan klarifikasi dengan dokter. Apabila klarifikasi gagal maka koder dapat menggunakan rule MB 1 hingga MB 5 untuk memilih kembali kode diagnosis utama (reseleksi). (Permenkes RI, 2016)

Pembayaran pelayanan kesehatan melalui INA-CBG berdasarkan pengajuan klaim FKRTLyang terlebih dahulu dilakukan verifikasi oleh verifikator BPJS Kesehatan. Hal tersebut untuk menguji kebenaran administrasi pertanggung jawaban pelayanan yang telah dilaksanakan oleh fasilitas kesehatan. (Permenkes RI, 2014)

Berdasarkan survei pendahuluan di RSUP dr. Soeradji Tirtonegoro Klaten ditemukan perbedaan kode diagnosis utama pada 5 dari 10 dokumen rekam medis pasien
BPJS kasus persalinan sebelum dan sesudah verifikasi. Dalam aturan koding ICD-10 kasus persalinan memiliki aturan khusus pada Bab $\mathrm{XV}$ dimana ditemukan kode utama tidak tepat.

Salah satu contoh, pasien dengan diagnosis utama Post SC emergency dan diagnosis sekunder induksi oxytocin gagal serta pemasangan IUD dikode diagnosis utama O13 (Gestational hypertention). Kode diagnosis utama yang tepat dalam kasus tersebut adalah O61.0 (Failed medical induction of labour, by: Oxytocin) dimana kode O82.1 (Delivery by emergency caesarean section) di reseleksi sesuai dengan aturan koding ICD-10.

Widyaningrum (2015) menyatakan bahwa ada hubungan yang signifikan ketepatan reseleksi kode diagnosis utama dengan pembiayaan di rumah sakit, sehingga tujuan penelitian ini adalah untuk mengetahui ketepatan kode diagnosis utama kasus persalinan sebelum dan sesudah verifikasi pada pasien BPJS di RSUP dr. Soeradji Tirtonegoro Klaten.

\section{METODE PENELITIAN}

Jenis penelitian ini adalah analitik komparatif dengan pendekatan cross sectional. Populasi sebanyak 199 dokumen rekam medis pasien rawat inap JKN BPJS kasus persalinan Triwulan I tahun 2017. Besar sampel sebanyak 50 dokumen, teknik pengambilan sampel sistematis random sampling. Instrumen penelitian berupa checklist dan daftar pertanyaan. Cara pengumpulan data melalui observasi dan wawancara tidak terstruktur. Teknik pengolahan data menggunakan collecting, editing, coding, entering, processing, cleaning dan penyajian data. Analisis data menggunakan uji Fisher exact test.

\section{HASIL PENELITIAN}

Tata cara pengodean dan proses reseleksi kode diagnosis utama kasus persalinan

Pengodean penyakit di RSUP dr. Soeradji Tirtonegoro Klaten menggunakan ICD-10 elektronik versi 2010 dengan format PDF document. Adapun langkah-langkah 
pengodean kasus persalinan adalah:

a. Berkas rekam medis dari assembling akan diberi kode berdasarkan ICD-10 volume 1 dan 3

b. Petugas mengecek kelengkapan lembar Discharge Summary

c. Petugas melakukan review kelengkapan informasi dalam dokumen rekam medis pasien

d. Apabila lengkap, berikan kode penyakit dan kode tindakan pada kotak yang telah disediakan di lembar Discharge Summary sesuai diagnosis yang ditegakkan dokter.

e. Dalam kasus persalinan petugas koding melakukan reseleksi kode diagnosis utama berdasarkan petunjuk untuk bab spesifik pada ICD-10 apabila diagnosis utama yang ditegakkan dokter merupakan metode persalinan.

f. Lembar verifikasi INA-CBG diberi kode berdasarkan ICD-10 pada kolom yang disediakan

g. Petugas mengecek kelengkapan lembar Resume

h. Jika lengkap berikan kode penyakit dan tindakan pada kolom yang telah disediakan dalam lembar Verifikasi INA-CBG sesuai diagnosis dan tindakan pada Discharge Summary

i. Apabila belum lengkap dikembalikan oleh IPPP

j. Lembar Verifikasi INA-CBG's yang telah selesai dikoding diambil kembali oleh IPPP

Ketepatan kode diagnosis utama kasus persalinan sebelum dilakukan verifikasi pada pasien BPJS

Berdasarkan hasil wawancara dengan petugas koding rawat inap dan verifikator internal, informasi yang diperlukan untuk menunjang ketepatan kode diagnosis utama kasus persalinan adalah Lembar Resume (Discharge summary) untuk mengetahui diagnosis yang ditegakkan dokter, Lembar Hasil Pemeriksaan Lab untuk mengetahui kondisi tertentu pada pasien, Lembar Hasil Pemeriksaan Radiografi (USG) untuk mengetahui kondisi janin dan yang melingkupinya, Informed Consent, dan Laporan Operasi.

Tabel 1. Ketepatan Kode Diagnosis Utama Kasus Persalinan Sebelum Verifikasi

\begin{tabular}{clcc}
\hline No & Ketepatan & Jumlah & $\mathbf{\%}$ \\
\hline 1 & Tepat & 25 & 50 \\
2 & Tidak Tepat & 25 & 50 \\
\hline & Total & 50 & 100 \\
\hline
\end{tabular}

Berdasarkan hasil analisis 50 dokumen rekam medis pasien rawat inap kasus persalinan di RSUP dr. Soeradji Tirtonegoro Klaten, sebesar $50 \%$ tepat dalam penentuan kode diagnosis utama dan $50 \%$ tidak tepat dalam penentuan kode diagnosis utama

Ketepatan kode diagnosis utama kasus persalinan sesudah dilakukan verifikasi pada pasien BPJS

Tabel 2. Ketepatan Kode Diagnosis Utama Kasus Persalinan Sesudah Verifikasi

\begin{tabular}{clcc}
\hline No & Ketepatan & Jumlah & $\mathbf{\%}$ \\
\hline 1 & Tepat & 29 & 58 \\
2 & Tidak Tepat & 21 & 42 \\
\hline & Total & 50 & 100 \\
\hline
\end{tabular}

Berdasarkan hasil analisis 50 berkas verifikasi pasien rawat inap kasus persalinan di RSUP dr. Soeradji Tirtonegoro Klaten, sebesar $58 \%$ tepat dalam penentuan kode diagnosis utama dan $42 \%$ tidak tepat dalam penentuan kode diagnosis utama

Perbedaan ketepatan diagnosis utama kasus persalinan sebelum dan sesudah verifikasi pada pasien BPJS

Tabel 3. Perbedaan Ketepatan Kode Diagnosis Utama Kasus Persalinan Sebelum dan Sesudah Verifikasi

\begin{tabular}{ccccc}
\hline & \multicolumn{4}{c}{ Kode Diagnosis Utama } \\
\hline Status & Tepat & Tidak & $P$ & $\mathbf{X}^{2}$ \\
Verifikasi & & Tepat & value & hitung \\
& $\mathrm{N}$ & $\mathrm{n}$ & & \\
Sebelum & 25 & 25 & 0,274 & 0,644 \\
Sesudah & 29 & 21 & & \\
\hline Jumlah & 54 & 46 & & \\
\hline
\end{tabular}


Berdasarkan Tabel 3, nilai signifikan $\mathrm{p}>$ $0,05(0,274>0,05)$ dan $X_{\text {hitung }}^{2} \leq X^{2}$ tabel $(0,644 \leq$ 3,841) maka $\mathrm{H}_{0}$ diterima dan $\mathrm{H}_{1}$ ditolak. Sehingga tidak ada perbedaan ketepatan kode diagnosis utama kasus persalinan sebelum dan sesudah verifikasi pada pasien BPJS di RSUP dr. Soeradji Tirtonegoro Klaten Triwulan I tahun 2017.

\section{PEMBAHASAN}

Tata cara pengodean dan proses reseleksi kode diagnosis utama kasus persalinan di RSUP dr. Soeradji Tirtonegoro Klaten

Pengodean diagnosis kasus persalinan di RSUP dr. Soeradji Tirtonegoro Klaten sesuai dengan SPO HK.02.04.2/I.4.12/279/2015 tentang Coding Rawat Inap sebagai berikut:

a. Berkas rekam medis dari assembling akan diberi kode dengan alphanumeric berdasarkan ICD-10 volume 1 dan 3

b. Petugas mengecek kelengkapan lembar Discharge Summary

c. Apabila lengkap, berikan kode penyakit dan tindakan pada kotak yang disediakan di lembar Discharge Summary sesuai dengan diagnosis yang ditulis dokter. Penetapan kode penyakit dan tindakan dikuatkan dengan adanya Lembar Laporan Operasi serta Laporan Anastesi

d. Lembar verifikasi INA-CBG's yang telah diterima dari IPPP akan diberi kode dengan alphanumeric berdasarkan buku ICD-10 volume 1 dan 3 pada kolom yang disediakan

e. Petugas mengecek kelengkapan lembar Resume

f. Jika lengkap berikan kode penyakit dan tindakan pada kolom yang disediakan dalam lembar Verifikasi INA-CBG's sesuai diagnosis dan tindakan yang tertulis di Discharge Summary

g. Apabila belum lengkap dikembalikan oleh IPPP

h. Lembar Verifikasi INA-CBG's yang telah selesai dikoding diambil kembali oleh IPPP

Selain itu, berdasarkan hasil wawancara, dalam pengodean kasus persalinan juga telah sesuai dengan (Hatta, 2014) yang menyebutkan cara pengodean sebagai berikut:

a. Lihat daftar tabulasi (volume 1) untuk mencari nomor kode yang paling tepat. Lihat kode ketiga karakter di index dengan tanda minus pada posisi keempat yang berarti bahwa isian untuk karakter keempat itu ada didalam volume 1 dan merupakan posisi tambahan yang tidak ada dalam index (vol.3). Perhatikan juga perintah untuk membubuhi kode tambahan (additional code).

b. Ikuti pedoman inclusion dan exclusion pada kode yang dipilih atau pada bagian bawah suatu bab (Chapter), blok, kategori, sub kategori

c. Lakukan analisis kuantitatif dan kualitatif data diagnosis yang dikode untuk pemastian kesesuaiannya dengan pernyataan dokter tentang diagnosis utama di berbagai lembar formulir rekam medis pasien.

Namun di RSUP dr. Soeradji Tirtonegoro Klaten belum terdapat SPO yang mengatur terkait tata cara reseleksi kode diagnosis utama.

\section{Ketepatan kode diagnosis utama kasus persalinan sebelum dilakukan verifikasi pada pasien BPJS}

Berdasarkan hasil analisis ketepatan kode diagnosis utama kasus persalinan sebelum dilakukan verifikasi BPJS, 25 (50\%) kode diagnosis utama tepat dan 25 (50\%) kode diagnosis utama tidak tepat. Kode diagnosis utama kasus persalinan tidak tepat disebabkan penulisan diagnosis utama yang kurang spesifik, dimana di RSUP dr. Soeradji Tirtonegoro Klaten format kolom kode diagnosis pada Lembar Resume (Discharge Summary) tidak dibedakan menjadi diagnosis utama dan diagnosis sekunder, tetapi seluruh kode diagnosis hanya terdapat pada satu area di kolom Kode Diagnosis Akhir. Sehingga berdasarkan wawancara dengan petugas, diagnosis utama diasumsikan sebagai diagnosis yang pertama ditulis oleh dokter pada kolom Diagnosis Akhir.

Selain itu, dokter maupun perawat 
terkadang tidak menuliskan keterangan secara lengkap pada formulir rekam medis pasien yang dapat berpengaruh pada kode, misal waktu kejadian Ketuban Pecah Dini yang tidak dituliskan secara rinci pada Lembar Pengkajian Awal IGD. Hal ini sesuai dengan penelitian (Setianto, 2013) menyatakan bahwa penulisan diagnosis utama yang tidak spesifik akan menghasilkan kode diagnosis utama yang tidak tepat lebih besar dibanding dengan penulisan diagnosis utama yang spesifik.

Selain itu, dikutip dari (Hueter, 2012) dokumentasi oleh tenaga kesehatan sangat penting untuk pengkodean ICD 10 . Komunikasi antar tenaga kesehatan juga diperlukan untuk mendapatkan data yang akurat agar perawatan pasien tepat penangamatan seperti dalam (Pain et al., 2017) menyebutkan bahwa peningkatkan hubungan antara berbagai profesi kesehatan dan interpretasi informasi klinis dari profesi lain dapat mengurangi frekuensi kesalahan komunikasi, sehingga dapat meningkatkan perawatan pasien.

Kode diagnosis utama yang tidak tepat juga disebabkan oleh koder yang salah dalam menetapkan kode diagnosis utama. Berdasarkan hasil wawancara, salah satu penyebab kesalahan penetapan kode diagnosis utama ini disebabkan penulisan diagnosis utama oleh dokter yang sering menuliskan metode persalinan, misal SC emergency, sebagai diagnosis utama. Hal ini berbeda dengan aturan koding ICD-10 dimana penggunaan kode (O80 - O84) untuk diagnosis utama terbatas pada kasus-kasus ketika informasi yang tercatat dalam rekam medis hanya mengenai kelahiran, sehingga koder akan menganalisis dan menentukan kode diagnosis utama berdasarkan diagnosis lain yang telah ditegakkan dokter selain metode persalinan dan merupakan penyulit selama masa kehamilan maupun persalinan yang lebih layak dijadikan kode diagnosis utama.

$\mathrm{Namun,}$ analisis ini harus memperhatikan struktur kode yang terdapat di dalam ICD-10, aturan yang berlaku dalam pengodean dan patofisiologi pada kehamilan maupun persalinan, karena dalam kasus persalinan antara diagnosis satu dengan lainnya memiliki keterkaitan dan manifestasi dari kondisi lainnya. Pada kondisi ini seringkali koder salah dalam menentukan kode diagnosis utama sebagaimana ditemukan dalam hasil analisis ketepatan kode diagnosis utama

Contoh:

DRMP5

Diagnosis Utama : Post partus spontan

Diagnosis Sekunder :-

a. Kode RS

Kode Diagnosis Utama:

O13 (Gestational [pregnancy-induced]

hpertention without significant proteinuria)

Kode Diagnosis Sekunder:

O80.0(Spontaneous vertex delivery)

Z37.0 (Single live birth)

b. Kode yang tepat

Kode Diagnosis Utama:

O80.0(Spontaneous vertex delivery)

Kode Diagnosis Sekunder:

Z37.0 (Single live birth)

Pada kasus P5 dokter menegakkan diagnosis Post partus spontan dan tidak terdapat diagnosis sekunder. Koder rumah sakit menetapkan kode O13 (Gestational [pregnancyinduced] hpertention without significant proteinuria) sebagai kode diagnosis utama. Sedangkan dokter tidak menegakkan diagnosis hipertensi pada pasien tersebut dan tidak ada informasi yang tercatat dalam dokumen rekam medis yang menunjukkan bahwa pasien tersebut mengalami hipertensi. Sehingga kode O80.0 (Spontaneous vertex delivery) layak dijadikan kode diagnosis utama.

\section{Ketepatan kode diagnosis utama kasus persalinan sesudah dilakukan verifikasi pada pasien BPJS}

Berdasarkan hasil analisis ketepatan kode diagnosis utama kasus persalinan sesudah dilakukan verifikasi BPJS, 29 (58\%) kode diagnosis utama tepat dan 21 (42\%) kode diagnosis utama tidak tepat. Kode diagnosis utama tidak tepat sesudah verifikasi memiliki 
faktor yang sama dengan penyebab kode diagnosis utama tidak tepat pada tahap sebelum verifikasi seperti penjelasan diatas. Peningkatan ketepatan kode diagnosis utama pada tahap sesudah verifikasi disebabkan verifikator internal terkait kode diagnosis sejumlah 6 orang merupakan lulusan D3 Kebidanan yang memiliki lebih banyak wawasan dalam hal persalinan.

Namun hal ini tidak menjamin jumlah ketepatan kode diagnosis utama mengalami kenaikan yang cukup besar, karena berdasarkan hasil wawancara verifikator internal tidak menggunakan ICD-10 dalam verifikasi kode diagnosis sehingga jika ditemui kode yang tidak akurat terutama pada kode karakter ke-4, verifikator jarang bisa mendeteksi. Sedangkan (Watkins, 2013) menyebutkan bahwa pengkodean yang akurat menggunakan ICD-10 akan memungkinkan pandangan yang lebih kaya ke dalam kualitas perawatan.

Ini juga menghasilkan analisis yang lebih baik dari pola penyakit dan hasil pengobatan yang dapat memajukan perawatan medis. Berdasarkan (Hueter, 2012) melakukan audit lengkap dari setiap kode yang dikodekan dan catatan yang disarikan akan memastikan kualitas data. Audit harus merupakan abstraksi ulang dari catatan untuk memastikan konsistensi dan akurasi data.

Namun, verifikator internal hanya mengoreksi kelengkapan berkas klaim yang sesuai dengan diagnosis dan tindakan yang dilakukan dan akan mengkonfirmasi jika diagnosis dirasa janggal dalam hal ketidaksesuaian dengan informasi penunjang.

\section{Perbedaan ketepatan diagnosis utama kasus persalinan sebelum dan sesudah verifikasi pada pasien BPJS}

Berdasarkan hasil analisis 50 dokumen rekam medis kasus persalinan pada pasien BPJS ketepatan kode diagnosis utama kategori tepat pada tahap sebelum verifikasi sebanyak $25(50 \%)$ dokumen rekam medis, kode diagnosis utama kategori tidak tepat pada tahap sebelum verifikasi sebanyak 25 (50\%) dokumen rekam medis, kode diagnosis utama tepat pada tahap sesudah verifikasi sebanyak 29 (58\%) dokumen rekam medis, dan kode diagnosis utama tidak tepat pada tahap sesudah verifikasi sebanyak 21 (42\%) dokumen rekam medis. Dari penjelasan tersebut yang perlu dijadikan pokok pembahasan adalah :

a. Keakuratan kode diagnosis utama

Faktor keakuratan kode akan berpengaruh dalam menunjang keakuratan data untuk pelaporan statistik rumah sakit (Hatta, 2014) dan klaim pembiayaan oleh BPJS. Pada 25 kode ketidaktepatan diagnosis utama sebelum verifikasi terdapat 9 kode yang tidak akurat di dalamnya dan pada 21 kode ketidaktepatan diagnosis utama sesudah verifikasi terdapat 8 kode yang tidak akurat di dalamnya.

Contoh:

1) Rumah Sakit

DRMP18

Diagnosis Utama : Post SCemergency

Diagnosis Sekunder :Induksi misoprostol gagal

Kode Diagnosis Utama:

O61.9 (Failed induction of labour, unspecified)

Kode Diagnosis Sekunder:

O82.1(Delivery by emergency caesarean section)

Z37.0 (Single live birth)

2) Peneliti

DRM P18

Diagnosis Utama : Post SC emergency

Diagnosis Sekunder : Induksi misoprostol gagal

Kode Diagnosis Utama:

O61.0 (Failed medical induction of labour, by: Oxytocin, Prostaglandins)

Kode Diagnosis Sekunder:

O82.1 (Delivery by emergency caesarean section)

Z37.0 (Single live birth)

Penetapan kode O61.0 (Failed medical induction of labour, by: Oxytocin, Prostaglandins) sebagai kode diagnosis utama berdasarkan aturan penggunaan kode $\mathrm{O} 80$ - 084 dalam ICD10 dimana kode-kode tersebut digunakan 
sebagai diagnosis sekunder untuk menunjukkan cara atau jenis kelahiran. Sedangkan kode O60.1 (Prolonged second stage (of labour)) lebih spesifik menunjukkan jenis induksi yang digunakan.

Pada Catatan Perkembangan Terintegrasi tercatat pasien mendapatkan injeksi misoprostol, dimana misoprostol (Cytotec) adalah prostaglandin $E_{1}$ sintetik, obat ini digunakan "off label" (diluar indikasi resmi) untuk pematangan serviks prainduksi dan induksi persalinan (Leveno et al., 2009).

Hal ini sesuai dengan (Hatta, 2014) untuk melihat daftar tabulasi (volume 1) untuk mencari nomor kode yang paling tepat, perhatikan juga perintah untuk membubuhi kode tambahan (additional code) serta aturan cara penulisan dan pemanfaatannya dalam pengembangan index penyakit dalam sistem pelaporan morbiditas dan mortalitas, serta ikuti pedoman inclusion dan exclusion pada kode yang dipilih atau pada bagian bawah suatu bab (Chapter), blok, kategori, dan sub kategori. Sehingga kode O61.0 (Failed medical induction of labour, by: Oxytocin, Prostaglandins)lebih layak dijadikan kode diagnosis utama

Contoh:

1) Rumah Sakit

DRM P4

Diagnosis Utama: Post SC elective

Diagnosis Sekunder : Disproporsi kepala panggul

Kode Diagnosis Utama:

O65.4(Obstructed labour due to fotopelvic disproportion, unspecified)

Kode Diagnosis Sekunder:

O82.0(Delivery by elective caesarean section) Z37.0 (Single live birth)

2) Peneliti

DRM P4

Diagnosis Utama : Post SC elective

Diagnosis Sekunder : Disproporsi kepala panggul

Kode Diagnosis Utama :

O33.9 (Maternal care for disproportion, unspecified)Cephalopelvic disproportion, NOS
Kode Diagnosis Sekunder :

O82.0 (Delivery by elective caesarean section) Z37.0 (Single live birth)

Penetapan kode O33.9 (Maternal care for disproportion, unspecified) dengan keterangan Cephalopelvic disproportion, NOS berdasarkan catatan include yang terdapat di awal kategori kode O33 menyatakan bahwa kondisi yang tercatat adalah sebagai penyebab dilakukannya observasi, perawatan di rumah sakit atau perawatan kehamilan lain bagi ibu, atau untuk dilakukannya caesarean section sebelum onset kelahiran. Pada P4 tindakan caesarean section yang dilakukan telah terencana, bukan karena macet yang dialami saat proses kelahiran.

Cephalopelvic disproportion terindikasi saat kehamilan sehingga dilakukan elective caesarean section. Jika Cephalopelvic disproportion menyebabkan kemacetan saat persalinan maka tindakan caesarean section yang dilaksanakan merupakan caesarean section untuk menangani kegawatan kemacetan saat persalinan (emergency caesarean section) bukan elective caesarean section. Sehingga kode O33.9 (Maternal care for disproportion, unspecified) Cephalopelvic disproportion, NOS layak dijadikan kode diagnosis utama.

b. Perbedaan ketepatan kode diagnosis utama Pada hasil analisis ditemukan 5 perbedaan ketepatan kode diagnosis utama kasus persalinan sebelum dan sesudah verifikasi dari Tidak Tepat menjadi Tepat dan 1 perbedaan ketepatan kode diagnosis utama kasus persalinan sebelum dan sesudah verifikasi dari Tepat menjadi Tidak Tepat

1) Sebelum Verifikasi Kode Diagnosis Utama Tidak Tepat $><$ Sesudah Verifikasi Kode Diagnosis Utama Tepat

DRMP10

Diagnosis Utama: Post SC emergency

Diagnosis Sekunder: Induksi oksitosin gagal

a) Kode Diagnosis Sebelum Verifikasi Kode Diagnosis Utama : O63.9 (Long labour, unspecified)

Kode Diagnosis Sekunder : O82.1 (Delivery by elective caesarean section) 
O61.0 (Failed medical induction of

labour)

Z37.0 (Single live birth)

Ketepatan : Tidak Tepat

b) Kode Diagnosis Sesudah Verifikasi

Kode Diagnosis Utama : O61.0 (Failed

medical induction of labour)

Kode Diagnosis Sekunder :

O82.1 (Delivery by elective caesarean section)

Z37.0 (Single live birth)

Ketepatan : Tepat

Penetapan kode diagnosis utama O61.0 (Failed medical induction of labour) dikarenakan tidak terdapat diagnosis long labour yang ditegakkan oleh dokter dan tidak tercatat adanya kondisi tersebut dalam dokumen rekam medis. Sehingga kode O61.0 (Failed medical induction of labour) layak menjadi kode diagnosis utama.

2)Sebelum Verifikasi Kode Diagnosis Utama Tepat $><$ Sesudah Verifikasi Kode Diagnosis Utama Tidak Tepat

DRMP33

Diagnosis Utama : Post SC elective

Diagnosis Sekunder : Gemelli letak lintang

a) Kode Diagnosis Sebelum Verifikasi

Kode Diagnosis Utama:

O30.0(Twin pregnancy)

Kode Diagnosis Sekunder :

O82.0 (Delivery by elective caesarean section)

Z37.2(Twins, bothliveborn)

Ketepatan : Tepat

b) Kode Diagnosis Sesudah Verifikasi

Kode Diagnosis Utama :

O64.8 (Obstructed labour due to other malpotition and malpresentation)

Kode Diagnosis Sekunder :

O82.0 (Delivery by elective caesarean section)

Z37.2 (Twins, bothliveborn)

Ketepatan: Tidak Tepat

Penetapan kode diagnosis utama O30.0 (Twin pregnancy) berdasarakan keterangan pada blok O30 - O48 mengenai perawatan kehamilan yang berkaitan dengan janin dan kandung amnion dan kemungkinan permasalahan persalinan, dimana kehamilan kembar pada P33 sudah diketahui sebelumnya dan direncanakan untuk caesarean section sebagai tindakan persalinan dan bukan karena kemacetan saat persalinan sebab janin kembar yang menjadi alasan dilaksanakannya caesarean section. Sehingga kode O30.0 (Twin pregnancy) layak menjadi kode diagnosis utama

c. Perbedaan Diagnosis Utama

Pada hasil analisis ditemukan 26 perbedaan diagnosis utama antara diagnosis yang terdapat dalam Lembar Discharge Summary dengan yang terdapat dalam Lembar Verifikasi

DRMP3

1) Sebelum Verifikasi (Lembar Discharge Summary)

Diagnosis Utama : Post VE

Diagnosis Sekunder : Kala II

Kode Diagnosis Utama :

O63.1 (Prolonged second stage)

Kode Diagnosis Sekunder :

O81.4 (Vacuum extractor delivery)

Z37.0 (Single live birth)

Ketepatan: Tepat

2) Sesudah Verifikasi (Lembar Verifikasi)

Diagnosis Utama : Maternal care for malpresentation offetus/unspecified

Diagnosis Sekunder : Prolonged second stage, vacuum extractor delivery

Kode Diagnosis Utama :

O63.1(Prolonged second stage)

Kode Diagnosis Sekunder:

O81.4 (Vacuum extractor delivery)

O32.9 (Maternal care for malpresentation of fetus, unspecified)

Z37.0 (Single live birth)

Ketepatan: Tepat

Perbedaan diagnosis terdapat pada Lembar Verifikasi, karena sebelum dilakukan verifikasi petugas koding sulit mengkonfirmasi langsung terkait diagnosis utama kepada DPJP sehingga petugas koding hanya melakukan reseleksi kode diagnosis utama berdasarkan aturan koding ICD-10 tanpa ada perubahan 
diagnosis utama oleh dokter pada lembar Discharge Summary.

Setelah masuk proses verifikasi terdapat dokter verifikator internal yang bertugas mengoreksi terkait diagnosis utama agar sesuai dengan perawatan dan pemeriksaan penunjang yang terdapat dalam berkas verifikasi. Diagnosis utama mengalami perubahan sesuai dengan aturan koding lainnya yang berlaku untuk INA-CBG dalam (Permenkes RI, 2016) terkait pengkodean untuk persalinan.

Dari pembahasan tersebut disimpulkan bahwa tidak ada perbedaan ketepatan diagnosis utama kasus persalinan sebelum dan sesudah verifikasi pada pasien BPJS. Meski demikian, angka ketidaktepatan kode diagnosis utama kasus persalinan sebelum verifikasi yang mencapai 25 (50\%) DRM dan ketidaktepatan kode diagnosis utama kasus persalinan sesudah verifikasi yang mencapai 21 (42\%) DRM perlu menjadi perhatian.

Perbedaan diagnosis utama yang ditegakkan dokter dengan kode diagnosis utama kasus persalinan menimbulkan perbedaan antara laporan statistik rumah sakit terkait dignosis utama dengan diagnosis utama yang terdapat pada Discharge Summary. Hal ini dapat berdampak pada pelaporan statistik rumah sakit yang tidak reliabel dan mutu rekam medis terkait inkonsistensi pencatatan.

Dikutip dari (Watkins, 2013) informasi yang melekat pada ICD-10 dapat menghasilkan pelaporan tren dan analitik yang lebih efektif sehingga rumah sakit dapat meningkatkan prediksi pemanfaatan sumber daya dengan lebih akurat.

Berdasarkan wawancara dengan koder rumah sakit dan verifikator internal rumah sakit, ketidaktepatan kode diagnosis utama dapat berpengaruh pada klaim BPJS, dimana pada kasus persalinan sering ditemukan selisih atau perbedaan antara biaya yang dikeluarkan rumah sakit dengan tarif yang ditetapkan oleh BPJS. Widyaningrum (2015) menyatakan, ada hubungan yang signifikan ketepatan reseleksi diagnosa dan kode utama diagnosa dokumen rekam medis dengan pembiayaan.

(Watkins, 2013) juga menyatakan, spesifisitas data klinis dan akurasi kode yang tepat akan memungkinkan rumah sakit mendapatkan penggantian klaim yang sesuai level.

Ketidaktepatan kode diagnosis utama yang tidak mengalami koreksi sesudah verifikasi juga disebabkan oleh verifikator internal yang tidak menggunakan ICD-10 untuk meneliti kembali kode terutama pada kode karakter ke-4.

Hal ini juga ditemukan dalam (Seruni and Sugiarsi, 2015) bahwa salah satu kelemahan terkait keakuratan kode diagnosis kasus obsterti adalah petugas yang tidak mengecek kembali pada ICD-10 volume 1 dan ketidaksesuaian SOP dengan aturan koding. Sebaiknya pengecekan terkait kode diagnosis tetap dilakukan karena dalam aturan pengodean pada INA-CBG dalam (Permenkes RI, 2016) mengadopsi dari ICD-10. Salah satu cara yang dapat dilakukan untuk mengatasi hal tersebut adalah dengan pembuatan SPO terkait koding untuk verifikasi klaim BPJS Kesehatan.

Berdasarkan permasalahan tersebut, maka lulusan D3 Rekam Medis dan Informasi Kesehatan dalam tim verifikasi internal sangat dibutuhkan, karena dalam proses verifikasi memerlukan keahlian evaluasi dokumen rekam medis guna menunjang keakuratan dan ketepatan kode.

Hal ini sesuai (Permenkes RI, 2013) Peraturan No 55 Tahun 2013 tentang Penyelenggaraan Pekerjaan Perekam Medis menyebutkan bahwa Ahli Madya Rekam Medis dan Informasi Kesehatan memiliki kompetensi untuk melaksanan sistem klasifikasi klinis dan kodefikasi penyakit yang berkaitan dengan kesehatan dan tindakan medis sesuai terminology medis yang benar, serta mampu melaksanakan evaluasi kelengkapan isi diagnosis dan tindakan sebagai ketepatan pengkodean.

Menurut (Harjanti and Ningtyas, 2018) hal tersebut dapat diatasi dengan perekrutan pegawai lulusan D3 Rekam Medis dan 
Informasi Kesehatan atau memberikan workshop/pelatihan pengkodean sesuai dengan sistem JKN kepada petugas verifikator internal yang telah ada. Sehingga dapat meminimalisir perbedaan persepsi antara petugas koding dengan verifikator internal rumah sakit.

Seperti yang terdapat dalam (Handayani, 2017) bahwa salah satu kendala dalam proses verifikasi administrasi klaim pasien JKN BPJS yaitu perbedaan persepsi koder dengan verifikator BPJS. Karena antara petugas koding dan verifikator internal memiliki kelimuan dan kompetensi yang sama sebagai lulusan D3 Rekam Medis dan Informasi Kesehatan, sehingga dalam proses verifikasi akan menghasilkan data kode diagnosis yang tepat sesuai aturan koding ICD-10 dan INACBG.

\section{PENUTUP}

Tidak ada perbedaan ketepatan kode diagnosis utama kasus persalinan sebelum dan sesudah verifikasi pada pasien BPJS. Disarankan dalam penentuan kode diagnosis utama didasarkan pada aturan koding dalam ICD-10 volume 2 serta verifikator internal tetap melakukan pengecekan kembali terkait kode diagnosis

\section{DAFTAR PUSTAKA}

Handayani, W. (2017) Tinjauan Proses Pelaksanaan Verifikasi Administrasi Klaim Pasien Jaminan Kesehatan Nasional di Unit Rawat Inap Rumah SakitUmum Daerah Kota Salatiga.

Harjanti and Ningtyas, N. K. (2018) 'Strategi Keakuratan Kode Diagnosis Berdasarkan metode SWOT', Manajemen Informasi Kesehatan Indonesia, 6(1), pp. 52-56.

Hatta, G. R. (2014) Pedoman Managemen Informasi Kesehatan di Sarana Pelayanan Kesehatan. Jakarta: Penerbit Universitas Indonesia.

Hueter, J. (2012) 'ICD-10 Learn From the Canadian Experience', Journal of Healthcare Information Management, 26(4), pp.16-17.
Leveno, K. J. et al. (2009) Obstetri Williams: panduan Ringkas Ed 21. Jakarta: EGC.

Pain, T. et al. (2017) ‘How are allied health notes used for inpatient care and clinical decision-making? A qualitative exploration of the views of doctors, nurses and allied health professionals', Health Information Management Journal, 46 ( 1 ), p p . 23-31. d o i : $10.1177 / 1833358316664451$.

Permenkes RI (2013) Peraturan Menteri Kesehatan Republik Indonesia Nomor 55 Tahun 2013 Tentang Penyelenggaraan Pekerjaan Perekam Medis. Jakarta, Indonesia.

Permenkes RI (2014) Peraturan Menteri Kesehatan Republik Indonesia Nomor 28 Tahun 2014 Tentang Pedoman Pelaksanaan Program Jaminan Kesehatan Nasional. Jakarta, Indonesia.

Permenkes RI (2016) Peraturan Menteri Kesehatan Republik Indonesia Nomor 76 Tahun 2016 Tentang Pedoman Indonesian Case Base Groups (INA-CBG) Dalam Pelaksanaan Jaminan Kesehatan Nasional. Jakarta, Indonesia.

Seruni, F. D. A. and Sugiarsi, S. (2015) 'Problem Solving Cycle SWOT Keakuratan Kode Diagnosis Kasus Obstetri pada Lembar Masuk dan Keluar (RM 1A) Pasien Rawat Inap di RSUD Dr. Sayidiman Magetan', Manajemen Informasi Kesehatan Indonesia, 3(2), pp. 5-13.

Setianto, D. B. (2013) Tinjauan Keakuratan Penetapan Kode Diagnosis Utama Berdasarkan Spesifikasi Penulisan Diagnosa Utama Pada Dokumen Rekam Medis Rawat Inap di Rumah Sakit Permata Medika Semarang Periode 2012. Dian Nuswantoro. A v a i $1 \mathrm{able}$ a $\mathrm{t}$ : http://mahasiswa.dinus.ac.id/docs/skrip si/jurnal/12863.pdf.

Watkins, L. (2013) 'Capturing the Real-World Benefits of ICD-10', Journal of Healthcare Information Management, 27(3), pp. 24-25.

WHO (2010) International Statistical Clasification Of Diseases And Related Health Problems 
10th Revision. Volume 1 -3. Geneva, Switzerland: WHOPress.

Widyaningrum, L. (2015) ‘Ketepatan Reseleksi Diagnosa dan Kode Utama Berdasarkan
Aturan Morbiditas Pembiayaan Jaminan Kesehatan INA-CBGS', Manajemen Informasi Kesehatan Indonesia, 3(2), pp. 27-31. 